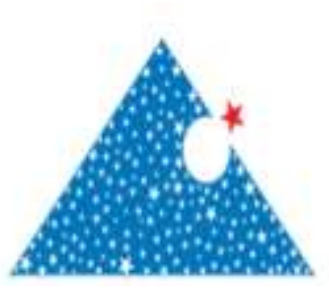

\title{
Novel Fumarate Derivatives Synthesis and Investigation of Acetylcholinesterase Inhibitor Properties
}

\author{
Günay KAYA KANTAR ${ }^{\mathrm{a}^{*}}$ \\ Department of Chemistry, Faculty of Art and Sciences, Recep Tayyip Erdogan University, 53100, Rize, Turkey \\ gunay.kaya@erdogan.edu.tr
}

Received/Geliș: 22.02.2021

Accepted/Kabul: 02.04.2021

\begin{abstract}
In this study, new fumarate compounds (I-IV) containing some natural phenols (eugenol, guaiacol, isoeugenol and vanillin) were synthesized and characterized. The single crystal X-ray diffraction technique was used to determine the crystal structures of all compounds. All compounds were evaluated as acetylcholinesterase (AChE) inhibitory, especially compound IV $\left(\mathrm{IC}_{50}=5.25 \pm 0.51 \mu \mathrm{g} / \mathrm{mL}\right)$, can be identified as a promising antiacetylcholinesterase agent due to its good inhibitory effect, when compared with donepezil hydrochloride $\left(\mathrm{IC}_{50}\right.$ $=16.02 \pm 0.66 \mu \mathrm{g} / \mathrm{mL}$ ) as used standard acetylcholinesterase inhibitory agent.
\end{abstract}

Keywords: X-ray, fumarate compound, acetylcholinesterase inhibition.

\section{Yeni Fumarat Türevlerinin Sentezi ve Asetilkolinesteraz Inhibitörü Etkilerinin Araştırılması}

\begin{abstract}
Öz: Bu çalışmada, bazı doğal fenolleri (öjenol, guayakol, izoöjenol ve vanilin) içeren yeni fumarat bileşikleri (IIV) sentezlenmiş ve karakterize edilmiştir. Tüm bileşiklerin kristal yapılarını belirlemek için tek kristal X-Işını kırınım tekniği kullanıldı. Tüm bileşikler asetilkolinesteraz (AChE) inhibitörü olabilecekmiş gibi değerlendirildi, özellikle bileşik IV $\left(\mathrm{IC}_{50}=5.25 \pm 0.51 \mu \mathrm{g} / \mathrm{mL}\right)$, donepezil hidroklorür $(\mathrm{IC} 50=16.02 \pm 0.66 \mu \mathrm{g} / \mathrm{mL})$ ile karşılaştırıldığında, iyi inhibe edici etkisinden dolayı umut verici anti-asetilkolinesteraz ajanı olarak tanımlanabilir.
\end{abstract}

Anahtar Kelimeler: X-ray, fumarat bileşikleri, asetilkolinesteraz inhibitörü

\section{Introduction}

Alzheimer's disease (AD) is a progressive brain disease in which memory, speech, people recognition, problem solving practices, reduced ability to perform daily tasks, memory and cognitive functions deteriorate over time, behavioral disorders and psychiatric symptoms can be seen. AD is a sneaky and slow-progressive dementia syndrome. The main strategy in the clinical treatment of $\mathrm{AD}$ involves the maintenance of adequate levels of acetylcholine (ACh) at neurotransmission sites [1]. Cholinesterase is a family of enzymes that catalyzes the hydrolysis of the neurotransmitter ACh into choline and acetic acid. Acetylcholinesterase (AChE) inhibitors inhibit the cholinesterase enzyme from breaking down $\mathrm{ACh}$, increasing both the level and duration of the neurotransmitter action. Thus, the inhibition of the AChE prevents the hydrolysis of ACh thereby maintaining normal memory function [2-4]. 
To date, many diaryl fumarates have been synthesized and examined for thermal decarboxylation to stilbenes [5]. However, the literature survey shows that the anti-acetylcholinesterase activities of diaryl fumarate compounds have not been investigated up to now.

Antioxidant, antibacterial and anti AChE activity of diarly oxalates containing eugenol and guaiacol were reported by our group [6]. It is predicted that enzyme inhibition is the binding of carbonyl groups to the esteric site of the enzyme. Therefore, it has been planned to investigate the AChE inhibition properties of new fumarate compounds in which the carbonyl groups are more distant from each other. It's expected that to increase the AChE inhibition of the newly synthesized compounds. The syntheses of four new fumarate compounds (I-IV) with some natural phenols (eugenol, guaiacol, isoeugenol and vanillin) were documented in this research. IR, ${ }^{13} \mathrm{C}-\mathrm{NMR},{ }^{1} \mathrm{H}-$ NMR and X-ray single-crystal were the methods used to validate the chemical structures of all compounds. Furthermore, acetylcholinesterase inhibition properties of new fumarate compounds were determined then compared both within themselves (I-IV) and with the literature [6].

\section{Experimental Methods}

\subsection{Materials}

Eugenol, guaiacol, isoeugenol, vanillin and fumaryl chloride were purchased from (Sigma, UK). FTIR spectra were recorded by Perkin-Elmer Spectrum 100 Infrared Spectrometer. UV/Vis spectra were recorded by Perkin-Elmer UV/vis spectrometer. ${ }^{1} \mathrm{H}$ NMR and ${ }^{13} \mathrm{C}$ NMR studies were performed by Agilent 400 FT-NMR. Elemental analyses (Leco / Truespec Micro) were performed by the Central Research Laboratory of the Recep Tayyip Erdoğan University.

\subsection{Synthesis}

The synthetic route of diarly fumarates containing eugenol (4-allyl-2-methoxy phenol), guaiacol (2methoxy phenol), isoeugenol (2-methoxy-4-(prop-1-en-1-yl) phenol) and vanillin (4-hydroxy-3methoxy benzaldehyde) can be seen in Scheme 1. Compounds (I-IV) were prepared according to the literatüre $[7,8]$.

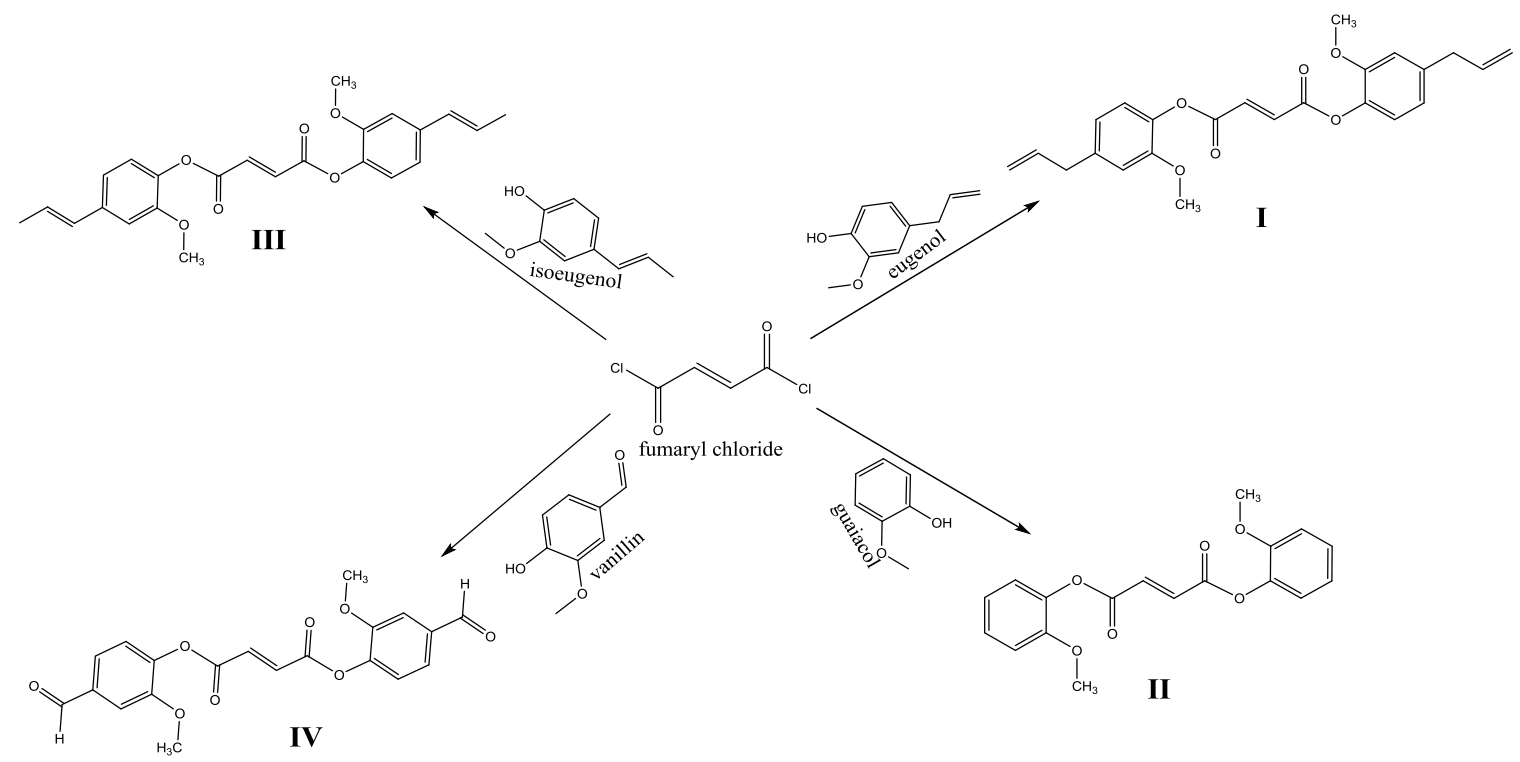

Figure 1. Synthesis route of compounds I, II, III and IV 


\subsubsection{General Synthesis Procedure of Fumarate Compounds (I-IV)}

To solutions of triethylamine $(2.5 \mathrm{~mL})$ and natural phenol compounds (Eugenol, guaiacol, isoeugenol, vanillin) $20 \mathrm{mmol}$ in THF $(15 \mathrm{~mL})$ was added fumaryl chloride $(10 \mathrm{mmol})$ respectively and stirred for $2 \mathrm{~h}$ at rt. Organic phase was washed with $\mathrm{NaOH}$ solution (\%20) and dried over anhydrous $\mathrm{Na}_{2} \mathrm{SO}_{4}$. Solvent was removed under reduced pressure and pure single crystals were obtained from THF by slow evaporation. Yield, melting points, elemental analysis, FTIR, ${ }^{1} \mathrm{H}-\mathrm{NMR}$,

${ }^{13} \mathrm{C}-\mathrm{NMR}$ spectra of the compounds (I-IV) are as follows.

\subsection{2 bis(4-allyl-2-methoxyphenyl) Fumarate (I)}

Yield: 90\%; m.p. 85-86 ${ }^{\circ} \mathrm{C}$. FTIR $v_{\max } \mathrm{cm}^{-1}: 3071,3008(\mathrm{Ar}-\mathrm{CH}), 2975,2943,2844,1736(\mathrm{C}=\mathrm{O})$, $1635,1604,1501,1466,1411,1294,1263,1189,1143,1117,1034,989,918,847,748 .{ }^{1} \mathrm{H}$ NMR $\left(\mathrm{DMSO}_{-} \mathrm{d}_{6}\right) \delta$, ppm: $7.14(2 \mathrm{H}, \mathrm{s}, \mathrm{ArCH}), 7.10-7.08(2 \mathrm{H}, \mathrm{d}, \mathrm{ArCH}), 6.98(2 \mathrm{H}, \mathrm{s},=\mathrm{CH}), 6.80-6.78$ $(2 \mathrm{H}, \mathrm{d},=\mathrm{C} \underline{\mathrm{H}}), 6.00-5.94(2 \mathrm{H}, \mathrm{m},=\mathrm{C} \underline{\mathrm{H}}), 5.13-5.04\left(4 \mathrm{H}, \mathrm{m},-\mathrm{C}_{2}\right), 3.75\left(6 \mathrm{H}, \mathrm{s}, \mathrm{OC}_{3}\right), 3.38-3.36$ $\left(4 \mathrm{H}, \mathrm{d},=\mathrm{CH}_{2}\right) .{ }^{13} \mathrm{C}$ NMR $\left(\mathrm{DMSO}-\mathrm{d}_{6}\right) \delta, \mathrm{ppm}: 162.91(\mathrm{C}=\mathrm{O}), 150.69,139.50,137.48,136.91$, 122.22, 120.70, 116.25, 112.81, 55.82, 40.09. Anal. Calcd. For $\mathrm{C}_{24} \mathrm{H}_{24} \mathrm{O}_{6}: \mathrm{C}, 70.58 ; \mathrm{H}, 5.92$ Found: C, 70.57; H, 5.93.

\subsection{3 bis(2-methoxyphenyl) Fumarate (II)}

Yield: 82\%; m.p. 174-175 ${ }^{\circ} \mathrm{C}$. FTIR $v_{\max } \mathrm{cm}^{-1} .3058,3020(\mathrm{Ar}-\mathrm{CH}), 2985,2948,2947,1739$ (C=O), 1604, 1497, 1466, 1442, 1280, 1262, 1171, 1125, 1107, 1019, 952, 780, 745. ${ }^{1} \mathrm{H}$ NMR (DMSO-d 6 ) $\delta$, ppm: 7.27-7.17 (8H, m, ArCH), $6.98(2 \mathrm{H}, \mathrm{s},=\mathrm{CH}), 3.77\left(6 \mathrm{H}, \mathrm{s}, \mathrm{OC}_{3}\right) .{ }^{13} \mathrm{C} \mathrm{NMR}\left(\mathrm{DMSO}-\mathrm{d}_{6}\right) \delta$, ppm: $162.69(\mathrm{C}=\mathrm{O}), 151.06,139.15,134.16,127.93,123.09,121.11,113.40,56.27$. Anal. Calcd. For $\mathrm{C}_{18} \mathrm{H}_{16} \mathrm{O}_{6}$ : C, 65.85; H, 4.91 Found: $\mathrm{C}, 65.83 ; \mathrm{H}, 4.92$.

\subsection{4 bis(2-methoxy-4-prop-1-en-1-yl) phenyl) Fumarate (III)}

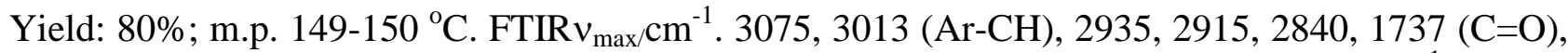
$1656,1599,1507,1465,1448,1415,1286,1262,1196,1153,1130,1030,961,863,756 .{ }^{1} \mathrm{H}$ NMR $\left(\mathrm{DMSO}_{-} \mathrm{d}_{6}\right) \delta$, ppm: $7.16(2 \mathrm{H}, \mathrm{s}, \mathrm{ArCH}), 7.15(2 \mathrm{H}, \mathrm{s},=\mathrm{CH}), 7.11-7.09(2 \mathrm{H}, \mathrm{d}, \mathrm{ArCH}), 6.97-6.95$ $(2 \mathrm{H}, \mathrm{d}, \mathrm{ArCH}), 6.43-6.30(4 \mathrm{H}, \mathrm{m},=\mathrm{CH}) 3.78\left(6 \mathrm{H}, \mathrm{s}, \mathrm{OCH}_{3}\right) 1.85-1.83\left(6 \mathrm{H}, \mathrm{d},-\mathrm{CH}_{3}\right) .{ }^{13} \mathrm{C} \mathrm{NMR}$ $\left(\mathrm{DMSO}_{6}\right) \delta$, ppm: $162.76(\mathrm{C}=\mathrm{O}), 151.04,137.99,137.46,134.14,130.60,126.76,123.01,118.57$, 110.28, 56.26, 18.66. Anal. Calcd. For $\mathrm{C}_{24} \mathrm{H}_{24} \mathrm{O}_{6}$ : C, 70.58; H, 5.92 Found: C, 70.57; H, 5.94.

\subsection{5 bis(4-formyl-2-methoxyphenyl) Fumarate (IV)}

Yield: 91\%; m.p. 181-182 ${ }^{\circ} \mathrm{C}$. FTIR $v_{\max } \mathrm{cm}^{-1} .3080(\mathrm{Ar}-\mathrm{CH}), 2948,2851,2756,1739$ and 1682 $(\mathrm{C}=\mathrm{O}), 1601,1499,1463,1425,1289,1260,1120,1030,992,841,729 .{ }^{1} \mathrm{H}$ NMR (DMSO-d 6 ) $\delta$, ppm: $9.98(2 \mathrm{H}, \mathrm{s}, \mathrm{O}=\mathrm{C} \underline{\mathrm{H}}) 7.65(2 \mathrm{H}, \mathrm{s}, \mathrm{ArCH}), 7.62-7.60(2 \mathrm{H}, \mathrm{d}, \mathrm{ArCH}), 7.49-7.47(2 \mathrm{H}, \mathrm{d}, \mathrm{ArCH})$, $7.24(2 \mathrm{H}, \mathrm{s},=\mathrm{CH}) 3.88\left(6 \mathrm{H}, \mathrm{s}, \mathrm{OCH}_{3}\right) .{ }^{13} \mathrm{C}$ NMR $\left(\mathrm{DMSO}-\mathrm{d}_{6}\right) \delta$, ppm: $192.51(\mathrm{C}=\mathrm{O}), 162.19(\mathrm{C}=\mathrm{O})$, 151.76, 143.89, 135.95, 134.19, 124.07, 124.00, 112.59, 56.65. Anal. Calcd. For $\mathrm{C}_{20} \mathrm{H}_{16} \mathrm{O}_{8}$ : C, 62.50; H, 4.20 Found: C, 62.50; H, 4.23.

\subsection{X-ray Crystallography}

Single-crystal X-ray diffraction data sets of I-IV were collected on a D8-QUEST diffractometer equipped with graphite-monochromatic Mo- $K_{\alpha}$ radiation at $296 \mathrm{~K}$. Structures were drawn with MERCURY [9]. Intermolecular interactions were analyzed and diagramed by using PLATON [10]. Crystallographic data of all the compounds are summarized in Table 1. 
Table 1 Crystal data and structure refinement parameters for compounds I-IV.

\begin{tabular}{lllll}
\hline Crystal data & \multicolumn{1}{c}{ I } & \multicolumn{1}{c}{ II } & \multicolumn{1}{c}{ III } & \multicolumn{1}{c}{ IV } \\
\hline Empirical formula & $\mathrm{C}_{24} \mathrm{H}_{24} \mathrm{O}_{6}$ & $\mathrm{C}_{18} \mathrm{H}_{16} \mathrm{O}_{6}$ & $\mathrm{C}_{24} \mathrm{H}_{24} \mathrm{O}_{6}$ & $\mathrm{C}_{20} \mathrm{H}_{16} \mathrm{O}_{8}$ \\
Formula weight & 408.43 & 328.31 & 408.43 & 384.33 \\
Crystal system & Monoclinic & Orthorhombic & Monoclinic & Monoclinic \\
Space group & $\mathrm{C} 2 / \mathrm{c}$ & $\mathrm{Pbca}$ & $\mathrm{P}_{1} / \mathrm{c}$ & $\mathrm{P}{ }_{1} / \mathrm{c}$ \\
$a(\AA)$ & $27.000(3)$ & $7.4627(9)$ & $15.2070(18)$ & $6.7444(4)$ \\
$b(\AA)$ & $5.1720(5)$ & $13.348(2)$ & $11.1632(11)$ & $7.7845(5)$ \\
$c(\AA)$ & $18.5917(19)$ & $16.250(2)$ & $12.8999(16)$ & $17.0903(11)$ \\
$\beta\left({ }^{\circ}\right)$ & $121.023(4)$ & 90.00 & $91.167(4)$ & $93.993(2)$ \\
$V\left(\AA^{3}\right)$ & $2224.8(4)$ & $1618.7(4)$ & $2189.4(4)$ & $895.09(10)$ \\
$\mathrm{Z}$ & 4 & 4 & 4 & 2 \\
$D_{\mathrm{c}}\left(\mathrm{g} \mathrm{cm}{ }^{-3}\right)$ & 1.219 & 1.347 & 1.239 & 1.426 \\
$\mu\left(\mathrm{mm}^{-1}\right)$ & 0.09 & 0.10 & 0.09 & 0.11 \\
$\theta$ range $\left({ }^{\circ}\right)$ & $3.1-24.4$ & $3.1-28.3$ & $3.2-28.3$ & $3.0-28.0$ \\
$\mathrm{Measured} \mathrm{refls.}_{\text {Independent refls. }}$ & 28535 & 27469 & 81374 & 22299 \\
$R_{\text {int }}$ & 2766 & 1997 & 4292 & 2209 \\
$\mathrm{~S}$ & 0.079 & 0.043 & 0.086 & 0.037 \\
$\mathrm{R}_{1} / \mathrm{wR}_{2}$ & 1.07 & 1.07 & 1.09 & 1.06 \\
$\Delta \rho_{\text {max }} / \Delta \rho_{\text {min }}\left(\mathrm{e} \AA^{-3}\right)$ & $0.43 /-0.28$ & $0.18 /-0.20$ & $0.80 /-0.67$ & $0.34 /-0.20$ \\
& & & &
\end{tabular}

\subsection{Biochemical Evaluation}

\subsubsection{Acetylcholinesterase Inhibition Assay}

Inhibitory properties of all compounds were subjected to the method of Ellman's method [11]. Acetylcholinesterase (Sigma-Aldrich) enzyme, the substrate (acetyl thiocholine chloride) and other solvents (phosphate buffer ( $\mathrm{pH} 8.0$ ), 5,5'-dithiobis(2-nitrobenzoic acid)) used in the study were prepared and analyzed to previously published literatüre [6].

AChE inhibition properties was expressed as \% inhibition activity of AChE and calculated $\mathrm{IC}_{50}$ values. Donepezil hydrochloride was used as a standart positive control.

\section{Results and Discussions}

\subsection{X-ray Crystallography Results}

According to XRD results, it is seen that I-IV have similar molecular structures. The geometric parameters of all molecules are given in Table 3. The molecular structures of compounds I-IV, with the atom numbering schemes, are reported in Figure 1. The combination of $\mathrm{C}(6)$ chains produce centrosymmetric $\mathrm{R}_{2}{ }^{2}(22)$ rings centered at $(1 / 2, n+1 / 2,1)(\mathrm{n}=$ zero or integer) (Figure 2 (a) ). In 
compound II, the combination of $\mathrm{C}-\mathrm{H} \cdots \mathrm{O}$ hydrogen bonds produces $\mathrm{R}_{4}{ }^{4}(26)$ rings which are parallel to the $a b$ plane (Figure 2 (b)). In compound IV, atom C9 in the molecule at $(\mathrm{x}, \mathrm{y}, \mathrm{z})$ acts as hydrogen-bond donors to the $\mathrm{C} 1 \sim \mathrm{C} 6$ phenyl ring in the molecule at (1-x, 1-y, 1-z), so forming a centrosymmetric $\mathrm{R}_{2}{ }^{2}(10)$ ring centered at $(1 / 2,1 / 2,1 / 2)$ (Figure 3 ).

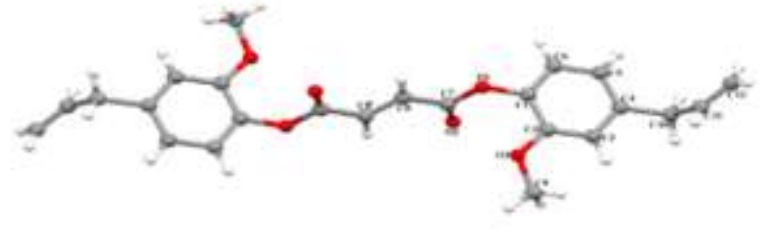

(I)

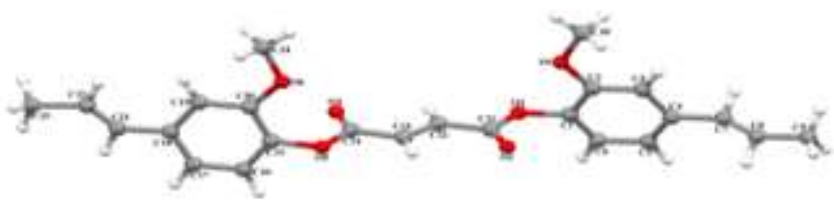

(III)

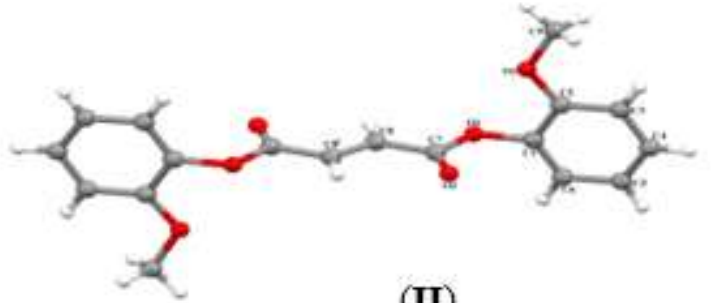

(II)

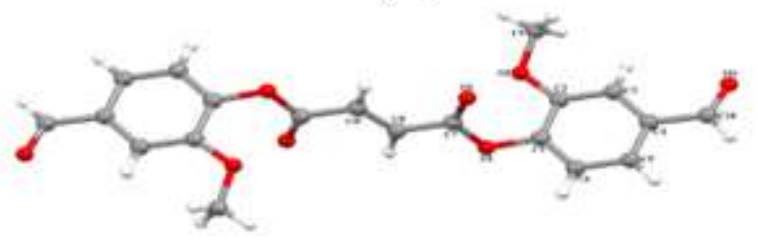

(IV)

Figure 1. The molecular structures of I-IV showing the atom numbering schemes. [(i) $-x+3 / 2$, $\mathrm{y}+1 / 2,-\mathrm{z}+2$ for I, (i) $-\mathrm{x},-\mathrm{y}+1,-\mathrm{z}+1$ for II and (i) $-\mathrm{x}+2,-\mathrm{y},-\mathrm{z}+1$ for IV]

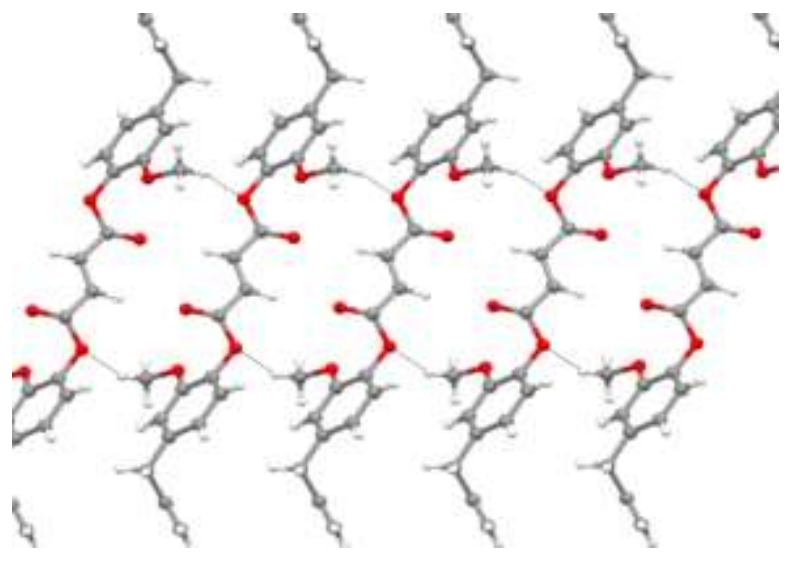

(a)

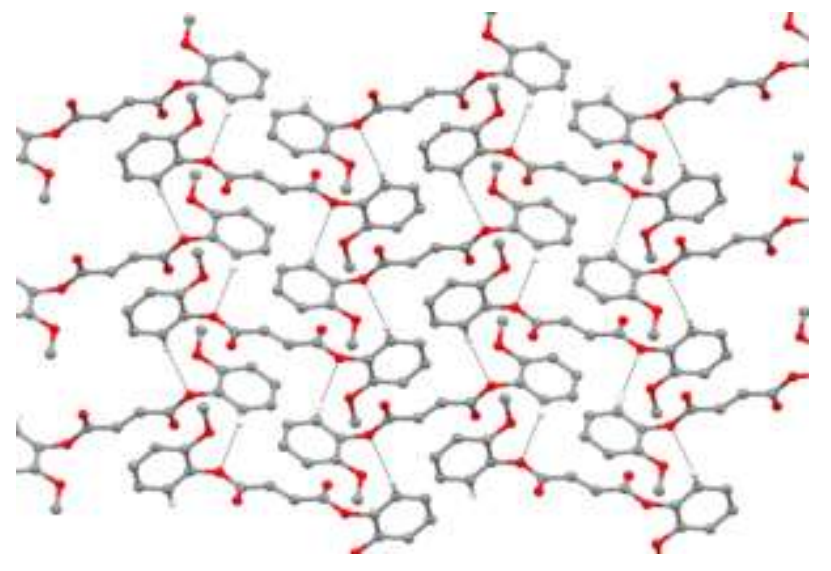

(b)

Figure 2. Crystal structures of I-II, showing the formation of $\mathrm{R}_{2}{ }^{2}(22)$ (a) and $\mathrm{R}_{4}{ }^{4}(26)$ (b) rings generated by $\mathrm{C}-\mathrm{H} \cdots \mathrm{O}$ hydrogen bonds.

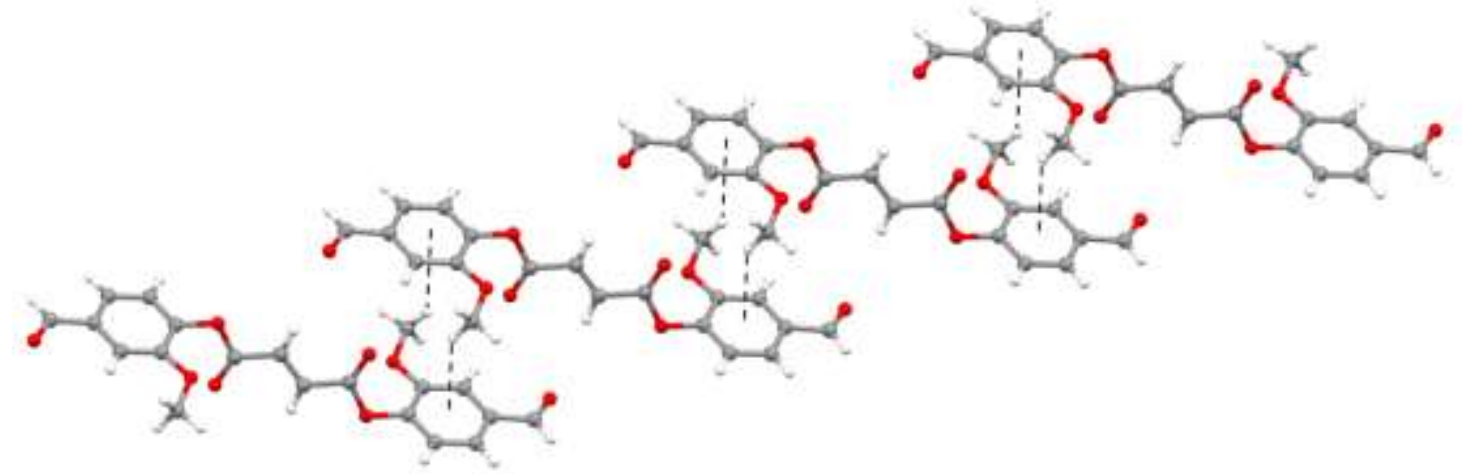

Figure 3. Crystal structure of IV, showing the formation of a chain along [110] generated by C$\mathrm{H}^{\cdots} \pi$ interactions. 


\subsubsection{Optimized Geometries}

Table 2 summarizes the calculated geometric parameters which were determined by DFT approach at the B3LYP/6-311G $(\mathrm{d}, \mathrm{p})$ level and experimental values of the compounds I-IV. As supported by Table 2, there is a small deviation between the optimized bond lengths and experimental data. On the contrary to the experimental method which processes several packing molecules in a concentrated environment, a theoretical determination is based on one molecule which is isolated in the gas phase. In conclusion, it is seen that experimental and theoretical structures were found to be compatible with each other. Additionally, computed geometric parameters estimate satisfactorily so they could be used to investigate the characteristics of the compounds.

Table 2. Selected bond lengths $(\AA)$, bond angles, torsion angles and dihedral angles $\left(^{\circ}\right)$

\begin{tabular}{lllllllll}
\hline & \multicolumn{2}{c}{ (I) } & \multicolumn{2}{c}{ (II) } & \multicolumn{2}{c}{ (III) } & \multicolumn{2}{c}{ (IV) } \\
\hline & X-ray & DFT & X-ray & DFT & X-ray & DFT & X-ray & DFT \\
\hline C1-O1 & $1.404(2)$ & 1.395 & $1.4116(18)$ & 1.395 & $1.410(5)-1.401(5)$ & 1.394 & $1.3960(16)$ & 1.388 \\
C7-O1 & $1.351(3)$ & 1.369 & $1.351(2)$ & 1.369 & $1.348(5)-1.332(5)$ & 1.369 & $1.3472(18)$ & 1.373 \\
C7-O2 & $1.196(3)$ & 1.200 & $1.194(2)$ & 1.200 & $1.206(5)-1.203(5)$ & 1.200 & $1.1982(18)$ & 1.199 \\
C2-O3 & $1.364(3)$ & 1.357 & $1.358(2)$ & 1.357 & $1.372(6)-1.357(6)$ & 1.357 & $1.3604(17)$ & 1.353 \\
C9-O3 & $1.406(3)$ & 1.422 & $1.429(2)$ & 1.422 & $1.415(7)-1.424(7)$ & 1.421 & $1.4252(19)$ & 1.427 \\
C9-O3-C2 & $118.1(2)$ & 118.6 & $117.38(15)$ & 118.4 & $117.8(4)-118.0(4)$ & 118.6 & $117.67(12)$ & 118.2 \\
O3-C2-C3 & $126.1(2)$ & 125.3 & $126.07(16)$ & 125.5 & $125.3(4)-127.6(5)$ & 123.3 & $125.75(14)$ & 125.7 \\
O3-C2-C1 & $115.4(2)$ & 116.2 & $116.37(14)$ & 116.1 & $115.1(4)-115.0(4)$ & 115.8 & $115.63(12)$ & 115.9 \\
C1-O1-C7 & $117.49(17)$ & 118.3 & $117.31(13)$ & 118.2 & $116.0(3)-116.7(3)$ & 118.3 & $116.91(11)$ & 118.4 \\
C4-C10-C11-C12 & $-117.4(5)$ & - & - & - & $-179.7(11)-178.4(8)$ & 179.9 & - & - \\
C2-C1-O1-C7 & $-71.7(3)$ & -722.1 & $-91.48(18)$ & -72.4 & $-77.9(5)--88.0(5)$ & -71.9 & $-67.82(17)$ & 112.6 \\
\hline
\end{tabular}

Table 3 Hydrogen bonds and $\mathrm{C}-\mathrm{H} \cdots \pi$ interaction parameters $\left(\AA,{ }^{\circ}\right)$

\begin{tabular}{llllll}
\hline Compound & D-H $\cdots$ A & D-H & $\mathrm{H}^{\cdots} \mathrm{A}$ & $\mathrm{D} \cdots \mathrm{A}$ & $\mathrm{D}-\mathrm{H} \cdots \mathrm{A}$ \\
\hline I & C9-H9A $\cdots \mathrm{O} 1^{\mathrm{ii}}$ & 0.96 & 2.53 & $3.401(3)$ & 151 \\
II & $\mathrm{C}^{\mathrm{i}}-\mathrm{H} 6 \cdots \mathrm{O} 1^{\mathrm{ii}}$ & 0.93 & 2.59 & $3.438(2)$ & 152 \\
III & $\mathrm{C} 3-\mathrm{H} 3 \cdots 3^{\mathrm{i}}$ & 0.93 & 2.56 & $3.400(6)$ & 150 \\
IV & $\mathrm{C} 9-\mathrm{H} 9 \mathrm{~A} \cdots \mathrm{Cg}(1)^{\mathrm{i}}$ & 0.96 & 3.00 & $3.786(2)$ & 140 \\
\hline
\end{tabular}

Symmetry codes: (ii) $\mathrm{x}, \mathrm{y}+1$, $\mathrm{z}$ for I; (ii) $\mathrm{x}-1 / 2,-\mathrm{y}+3 / 2,-\mathrm{z}+1$, for II; (i) $-\mathrm{x}+1$, $-\mathrm{y}+1,-\mathrm{z}+2$, for III; (i) $-\mathrm{x}+1,-\mathrm{y}+1,-\mathrm{z}+1$, for IV; $\mathrm{Cg}(1)=\mathrm{C} 1-\mathrm{C} 6$.

\subsection{AChE Inhibition Results}

All synthesized compounds were evaluated to $\mathrm{AChE}$ inhibition properties. It was determined that all compounds had a smaller $\mathrm{IC}_{50}$ value than donepezil as standard. The order of AChE inhibition effect of all compounds was found to be IV $>$ II $>$ I=III $>$ Donepezil. Dose-dependent AChE inhibition is shown in Figure 4.

The compound IV showed the best AChE inhibition with $\mathrm{IC}_{50}$ value $5.25 \pm 0.51 \mu \mathrm{g} / \mathrm{mL}$, among these compounds (Figure 4, Table 4). The compound IV can be identified as a promising acetylcholinesterase inhibition agent due to its inhibitory effect, when compared with Donepezil hydrochloride $\left(\mathrm{IC}_{50}=16.02 \pm 0.66 \mu \mathrm{g} / \mathrm{mL}\right)$.

Acetylcholinesterase inhibition of diarly oxalates containing eugenol and guaiacol was reported previously [6]. It was predicted that the carbonyl groups could be binding to the esteric site of the enzyme and inhibit the enzyme. 
Compound IV has aldehyde groups different from other compounds (I-III) which means an extra two carbonyl groups. These aldehyde groups, which have low steric efficiency, may have increased the inhibitory effect. The enzyme bond maybe both from the ester carbonyl and from the aldehyde carbonyl.

Fumarate compounds (I, II) having the same functional group have a higher inhibitory effect than oxalate compounds $(1,2)[6]$. This effect is by the predicted we think when starting to work. As the chain between the carbonyl groups is extended, the compounds are well bound to the enzyme and show better inhibition.

Table 4. Results of \% inhibition AChE and IC50 values of compounds and standard (donepezil hydrochloride).

\begin{tabular}{lcl}
\hline & \multicolumn{2}{c}{ Inhibition AChE Activity (\%) } \\
\hline Compounds & $\mathbf{6 0} \boldsymbol{\mu g} / \mathbf{m L}$ & $\mathbf{I C}_{\mathbf{5 0}}(\boldsymbol{\mu g} / \mathbf{m L})$ \\
\hline I & $87.72 \pm 1.23$ & $13.20 \pm 0.43$ \\
II & $90.80 \pm 0.98$ & $9.02 \pm 0.26$ \\
III & $86.72 \pm 0.78$ & $13.50 \pm 0.38$ \\
IV & $95.00 \pm 1.08$ & $5.25 \pm 0.51$ \\
Donepezil & $79.50 \pm 0.85$ & $16.02 \pm 0.66$ \\
\hline
\end{tabular}

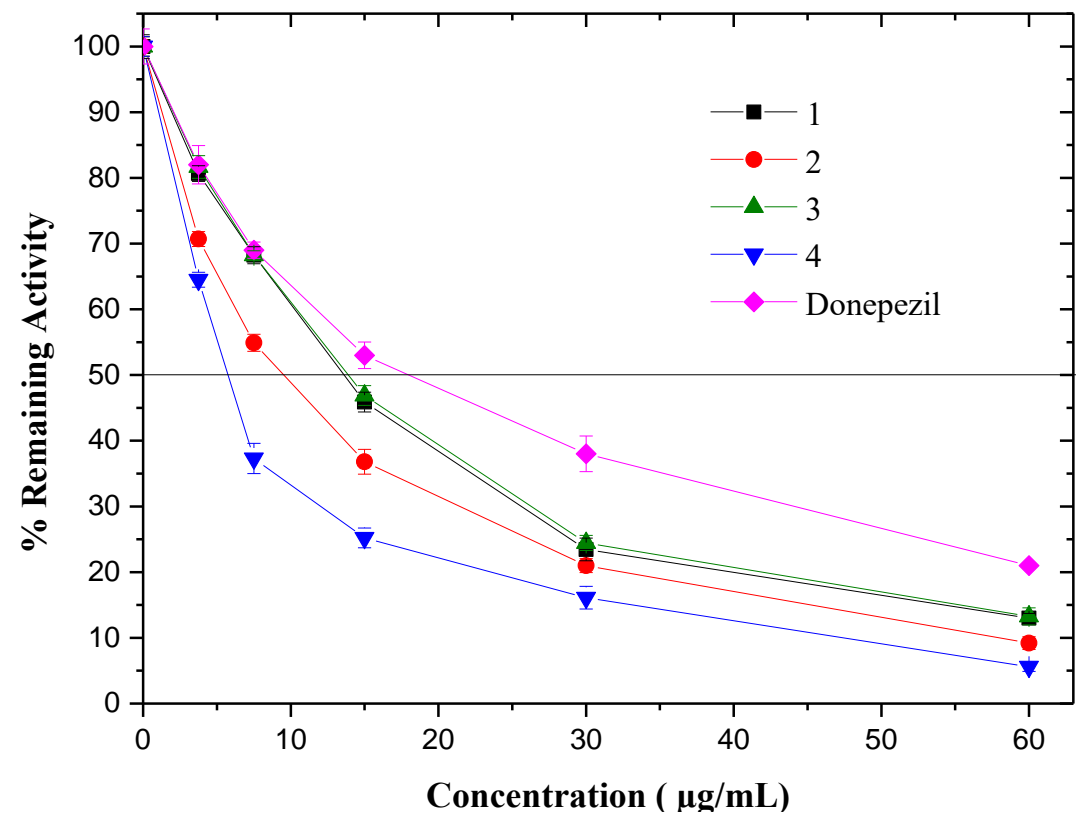

Figure 4. Dose-dependent inhibitory effect of all compounds and Donepezil were measured at the final concentration of $3.75-60 \mu \mathrm{g} / \mathrm{mL}$. Remaining activities were expressed as the mean $\pm \mathrm{SD}$ in triplicate

\section{Conclusions}

The novel fumarate compounds (I-IV) containing some natural phenols (eugenol, guaiacol, isoeugenol and vanillin) were obtained and characterized by IR, ${ }^{13} \mathrm{C}-\mathrm{NMR},{ }^{1} \mathrm{H}-\mathrm{NMR}$ and X-Ray analysis. Furthermore, acetylcholinesterase inhibition properties of new fumarate compounds were determined then compared both within themselves (I-IV) and in the literature. This work shows that; fumarate compounds (I, II) have a higher inhibitory effect than oxalate compounds $(1,2)$ 
having the same functional group. This result is as predicted when starting to work. As the chain between the carbonyl groups is extended, the compounds are well bound to the enzyme and show better inhibition. All compounds, especially IV, can be identified as promising acetylcholinesterase inhibitor due to their high inhibition effect when compared with Donepezil hydrochloride.

\section{Acknowledgements}

This study was supported by Recep Tayyip Erdoğan University under Project No: FBA-2016-697. The authors acknowledge Scientific and Technological Research Application and Research Center, Sinop University, Turkey, for the use of the Bruker D8 QUEST diffractometer.

\section{Authors' contributions}

GKK carried out the study and wrote up the article. Both authors read and approved the final manuscript.

\section{Competing interests}

The author(s) declare that they have no competing interests.

\section{References}

[1]. Öziç M.Ü., Özşen S., 3B Alzheimer MR Görüntülerinin Hacimsel Kayıp Bölgelerindeki Voksel Değerleri Kullanılarak Sinıflandırılması, El-Cezeri Journal of Science and Engineering, 2020, 7, 1152-66.

[2]. Howes M.J.R., Houghton P.J., Plants used in Chinese and Indian traditional medicine for improvement of memory and cognitive function, Pharmacol Biochem Be, 2003, 75, 513-27.

[3]. Houghton P.J., Howes M.J., Lee C.C., Steventon G., Uses and abuses of in vitro tests in ethnopharmacology: Visualizing an elephant, J Ethnopharmacol, 2007, 110, 391-400.

[4]. Wiener S.W., Hoffman R.S., Nerve agents: a comprehensive review, J Intensive Care Med, 2004, 19, 22-37.

[5]. Spatz S.M., Thermal decarboxylation of diaryl fumarates to stilbenes, J. Org. Chem., 1961, 26, 4158-61.

[6]. [6] Kantar G.K., Baltas N., Beris F.S., Sasmaz S., Acethylcholinesterase Inhibition, Antibacterial and Antioxidant Properties of Diaryl Oxalates, Curr. Enzyme Inhib., 2017, 13, 27-33.

[7]. Şahin Z.S., Kantar G.K., Şaşmaz S., Büyükgüngör O., Synthesis, molecular structure, spectroscopic analysis, thermodynamic parameters and molecular modeling studies of (2methoxyphenyl)oxalate, J Mol Struct, 2015, 1087, 104-12.

[8]. Şahin Z.S., Kantar G.K., Şaşmaz S., Büyükgüngör O., Theoretical and experimental investigations on molecular structure of bis(2-methoxy-4-allylphenyl)oxalate, J Mol Struct, 2016, 1103, 156-65.

[9]. Mercury, version 3.0; CCDC, available online via ccdc.cam.ac.uk/products/mercury.

[10]. Spek A.L., PLATON, a multipurpose crystallographic tool, Utrecht University, Utrecht, , 2005.

[11]. Ellman G.L., Courtney K.D., Andres V., Featherstone R.M., A new and rapid colorimetric determination of acetylcholinesterase activity, Biochem Pharmacol, 1961, 7, 88-95. 